\title{
Namen in uporabnost Digitalnega repozitorija COBISS (dCOBISS)
}

\author{
Applicability of COBISS Digital Repository (dCOBISS)
}

\section{Miran Petek ${ }^{1}$, Bojan Štok ${ }^{2}$, Branko Namestnik ${ }^{3}$, Andrej Krajnc ${ }^{4}$}

IZVLEČEK: IZUM je v letu 2020 izdal prvo verzijo Digitalnega repozitorija COBISS (dCOBISS), ki je samostojna spletna aplikacija, namenjena hranjenju in upravljanju digitalnih vsebin. Dostopna je vsem knjižnicam v sistemu COBISS in deluje po principih vzajemnega dostopa do objav v dCOBISS. Osnova in pogoj za dodajanje vseh vrst digitalnih vsebin je bibliografski zapis. $\vee$ prispevku so predstavljeni posamezni segmenti repozitorija ter druge obstoječe in predvidene funkcionalnosti. dCOBISS bo podpiral tudi analizo odprtega dostopa za slovenske raziskovalce, aplikacija pa se bo $v$ prihodnje razvijala v skladu s trendi, potrebami in hitro spreminjajočimi se razmerami v slovenskih knjižnicah in mednarodnih knjižničnih okoljih.

KLJUČNE BESEDE: dCOBISS, digitalni repozitoriji, OpenAIRE, orodja za odkrivanje podatkov, analitika odprtega dostopa

ABSTRACT: In 2020, IZUM released the first version of the COBISS Digital Repository (dCOBISS), which is an independent web app, intended for storing and managing digital content. It is available to all libraries in the COBISS system and it works by principles of shared access to publications in dCOBISS. A bibliographic record is required and it represents the basis for adding all types of digital content. Individual repository segments and other existing and foreseen functionalities are presented. Also open access analysis for Slovenian researchers will be supported by dCOBISS. In future, the dCOBISS app will be developed in compliance with trends, requirements and rapidly changing conditions in Slovenian libraries and in international library environments.

KEYWORDS: dCOBISS, digital repositories, OpenAIRE, discovery tools, open access analytics

\section{Uvod}

Aplikacija dCOBISS je 15. junija 2021 praznovala svoj prvi rojstni dan (Petek, 2020). Programska rešitev za hranjenje digitalnih vsebin, ki so jo knjižnice že dolgo pričakovale, se je znašla med razvojnimi produkti IZUM-a za zadovoljevanje knjižničnih potreb sodobnega časa. Prevlada digitalnih vsebin v svetu interneta in mobilnih naprav močno vpliva tudi na storitve knjižnic in njihovo prilagajanje potrebam svojih uporabnikov. Knjižnice se soočajo z očitno preobrazbo potreb bralcev in obiskovalcev, kar zahteva tudi prilagoditev orodij in aplikacij, ki jih knjižnice uporabljajo pri uresničevanju svojega poslanstva. Orodje za hranjenje digitalnih vsebin je logičen odgovor na zahteve trenutnega časa. IZUM-ov cilj je ustvariti zaupanja vreden digitalni repozitorij.

Aplikacija dCOBISS je zasnovana tako, da vsem knjižnicam v sistemu COBISS omogoča shranjevanje datotek $z$ digitalnimi vsebinami. dCOBISS je samostojna aplikacija, a tesno

\footnotetext{
${ }^{1}$ Korespondenčni avtor: Miran Petek, Institut informacijskih znanosti (IZUM), Maribor, Slovenija, miran.petek@izum.si.

2 Mag. Bojan Štok, Institut informacijskih znanosti (IZUM), Maribor, Slovenija, bojan.stok@izum.si.

${ }^{3}$ Mag. Branko Namestnik, Institut informacijskih znanosti (IZUM), Maribor, Slovenija, branko.namestnik@izum.si.

${ }^{4}$ Mag. Andrej Krajnc, Institut informacijskih znanosti (IZUM), Maribor, Slovenija, andrej.krajnc@izum.si.
} 
povezana z drugimi IZUM-ovimi produkti. Izhodišče pri snovanju aplikacije je bila racionalizacija katalogizacijskih in administrativnih postopkov upravljanja z metapodatki in datotekami. Osnova za objavo v dCOBISS je bibliografski zapis, kreiran v sistemu COBISS v bazi COBIB, s katerim povežemo datoteko, ki jo $v$ aplikaciji dCOBISS opišemo s potrebnimi metapodatki za prezentacijo in analitiko.

dCOBISS pokriva potrebe različnih tipov knjižnic. Knjižnice, ki želijo obogatiti bibliografske zapise z naslovnicami bibliografskih virov, lahko to uredijo prek dCOBISS-a. Knjižnice, ki hranijo vsebine, do katerih lahko dostopajo le določeni člani knjižnice, lahko dostop omejijo z avtorizacijo. Za akademske knjižnice sta zagotovljeni sinhronizacija z institucionalnimi digitalnimi repozitoriji in podpora pri analizi odprtega dostopa. Vse te funkcionalnosti, ki jih dCOBISS omogoča, so na voljo vsem knjižnicam v mreži COBISS.net, vendar lahko knjižnice zunaj Slovenije dostopajo zgolj do svojega nacionalnega repozitorija. Digitalne vsebine iz dCOBISS-a so najdljive in dostopne uporabnikom prek aplikacije COBISS+. Določene vsebine (članki, e-knjige, predstavitve ...) so najdljive in dostopne tudi kot celotna besedila, kar je še posebej pomembno za Akademsko digitalno zbirko Slovenije (ADZ), ki za slovenske akademske uporabnike predstavlja orodje za odkrivanje informacij (angl. discovery services).

Razvoj aplikacije dCOBISS še ni zaključen, saj pričakujemo, da bo v prihodnje vloga dCOBISS-a vse pomembnejša. dCOBISS vidimo tudi kot agregator vsebin vseh institucionalnih repozitorijev $v$ Sloveniji, torej kot nacionalni referenčni digitalni repozitorij. Kvalitetno oblikovan bibliografski zapis $v$ COBISS je osnova za najdljivost vsebine v COBISS+, skupaj z digitalnimi vsebinami, dodanimi $v$ dCOBISS, pa lahko uporabniku zagotovimo celovito storitev. Verjamemo, da skupaj s knjižnicami ustvarjamo storitve in servise, ki jih naši skupni uporabniki potrebujejo in od nas pričakujejo.

Nadaljnji razvoj aplikacije dCOBISS bo sledil potrebam slovenskih knjižnic. Povezovali se bomo $s$ tujimi informacijskimi sistemi $v$ mednarodnem okolju in sledili razvoju tujih ponudnikov podobnih rešitev. Knjižničarjem bomo olajšali delo z integracijami znotraj sistemov COBISS in SICRIS ter tako zagotavljali kvalitetne programske rešitve. Programsko opremo bomo prilagajali specifičnostim slovenskega okolja in ohranjali osnovno načelo vzajemnega delovanja v sistemu COBISS.

\section{Osnovne informacije o aplikaciji dCOBISS}

Digitalni repozitorij COBISS (2020) ali krajše dCOBISS je povsem nova samostojna spletna aplikacija IZUM-a, namenjena hranjenju digitalnih vsebin, ki jih knjižnice ponujajo svojim uporabnikom. Zgrajena je z najsodobnejšimi tehnološkimi programskimi orodji in preprosta za uporabo. Dostopna je na naslovu https://d.cobiss.net/repository/si. 


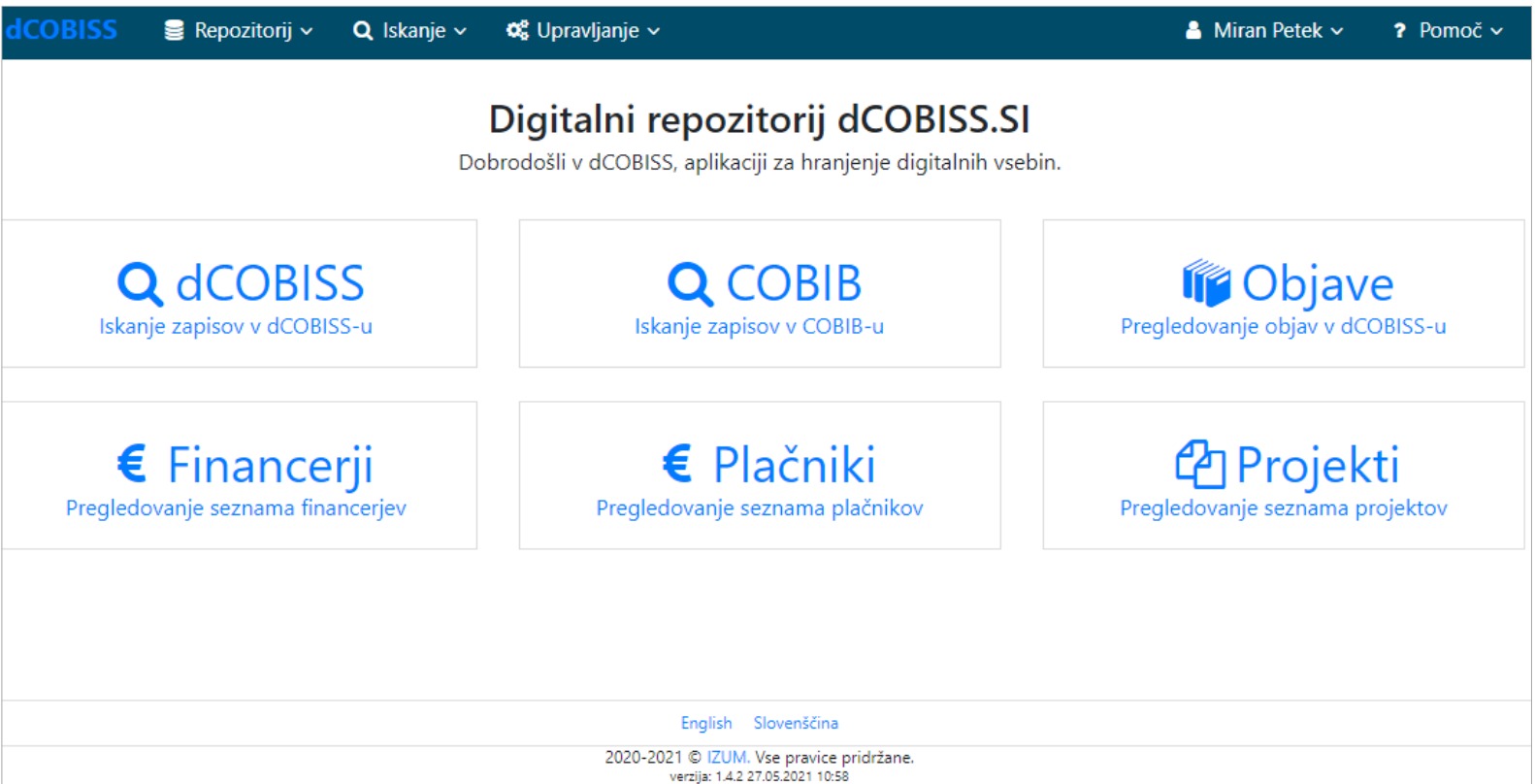

Slika 1: Vstopna stran aplikacije dCOBISS

Prva namestitev dCOBISS je bila izvedena 15. junija 2020. Vse slovenske knjižnice v sistemu COBISS jo lahko uporabljajo brezplačno. Do objave tega prispevka je bilo izvedenih nekaj nadgradenj aplikacije $z$ izboljšavami in novimi funkcionalnostmi. Trenutno je $v$ dCOBISS-u shranjenih skoraj 66.000 digitalnih objektov.

Aplikacija dCOBISS je samostojna (slika 1), vendar integrirana v preostale produkte sistema COBISS. Knjižničarji lahko iz segmenta COBISS3/Katalogizacija brez prijave prehajajo v dCOBISS in $\mathrm{k}$ bibliografskim zapisom dodajajo digitalne vsebine. Te digitalne vsebine so najdljive in dostopne končnim uporabnikom $v$ aplikaciji COBISS+. SICRIS predstavlja vir podatkov o projektih pri obdelavi objav avtorskih del slovenskih raziskovalcev, financiranih po programih Javne agencije za raziskovalno dejavnost RS (ARRS). Z razvojem nove verzije SICRIS bo integracija dCOBISS-a še tesnejša.

Obstoj bibliografskega zapisa v COBIB-u (veljaven COBISS-ID) je pogoj za kreiranje objave v aplikaciji dCOBISS in dodajanje digitalnih vsebin. Kreirano objavo lahko dopolnjujejo vse knjižnice v sistemu, objave in datoteke pa lahko briše le knjižnica, ki je objavo kreirala ali dodala datoteko. Ažuriranje bibliografskega zapisa v dCOBISS-u ni možno, to se lahko izvaja le v segmentu COBISS3/Katalogizacija.

V septembru 2020 smo omogočili uporabo aplikacije dCOBISS tudi sistemom v mreži COBISS.net (slika 2) (Digitalni repozitorij dCOBISS.net, 2020). Aplikacija je prevedena v vse uradne jezike, ki jih posamezni nacionalni sistemi uporabljajo. Vsak sistem ima svoj repozitorij. Knjižničarji lahko dostopajo le do svojega nacionalnega repozitorija. 


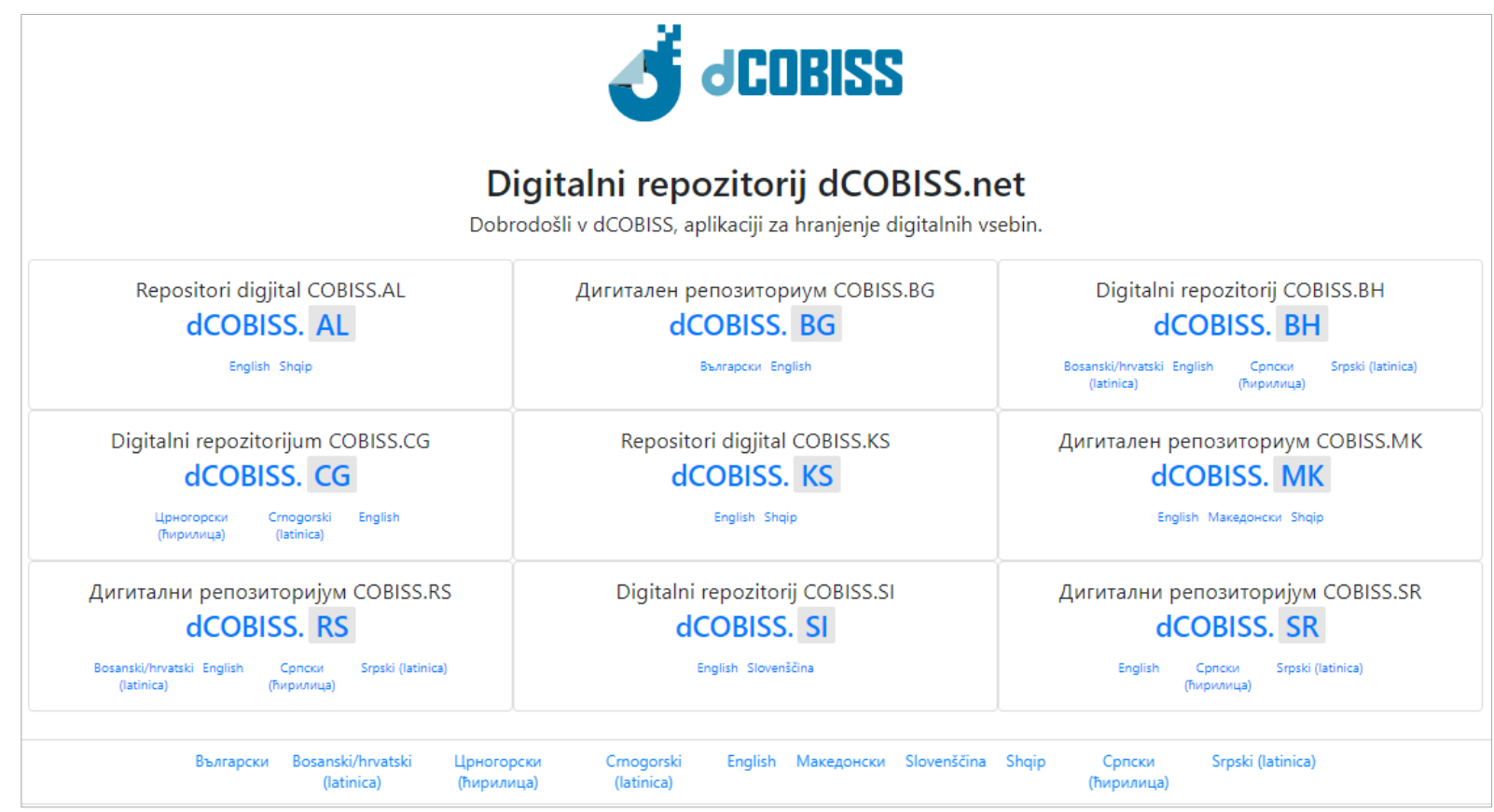

Slika 2: dCOBISS je dostopen v vseh sistemih mreže COBISS.net

dCOBISS je namenjen vnosu celotnih del slovenskih raziskovalcev, objavljenih $v$ odprtem dostopu, in bo služil za analizo odprtega dostopa, ki jo bodo potrebovali ARRS ter slovenske univerze in druge raziskovalne institucije. Med repozitorijem dCOBISS ter institucionalnimi univerzitetnimi in raziskovalnimi repozitoriji se izvaja sinhronizacija, s čimer se knjižničarju olajša delo pri vnosu potrebnih podatkov o objavah v odprtem dostopu.

Knjižnicam je na voljo testno okolje dCOBISS, v katerem lahko knjižničarji preizkušajo nove funkcionalnosti aplikacije dCOBISS, ki bodo kmalu na voljo v pravem, produkcijskem okolju. Knjižnici, ki želi uporabljati testno okolje dCOBISS, je treba namestiti testno okolje COBISS3, kar IZUM izvede na zahtevo knjižnice.

\section{Uporaba dCOBISS}

dCOBISS lahko uporabljajo vsi knjižničarji, ki imajo pooblastilo za vnos podatkov o zalogi v segmentu COBISS3/Zaloga. Za dostop do dCOBISS-a je obvezna prijava, ki je enaka prijavi v aplikaciji COBISS3. 


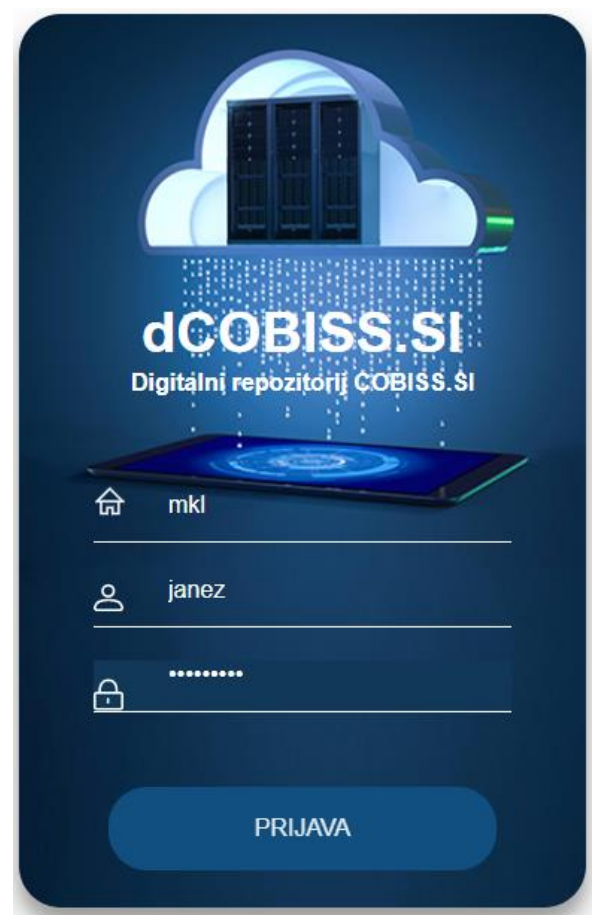

Slika 3: Prijava v dCOBISS

Knjižničar se lahko prijavi v dCOBISS neposredno (slika 3) ali prek aplikacije COBISS3. Kadar je knjižničar že prijavljen $v$ aplikacijo COBISS3, za dodajanje vsebin $v$ dCOBISS ni potrebna dodatna prijava (slika 4), saj je uporabljen koncept enotne prijave (angl. Single Sign-On, SSO).

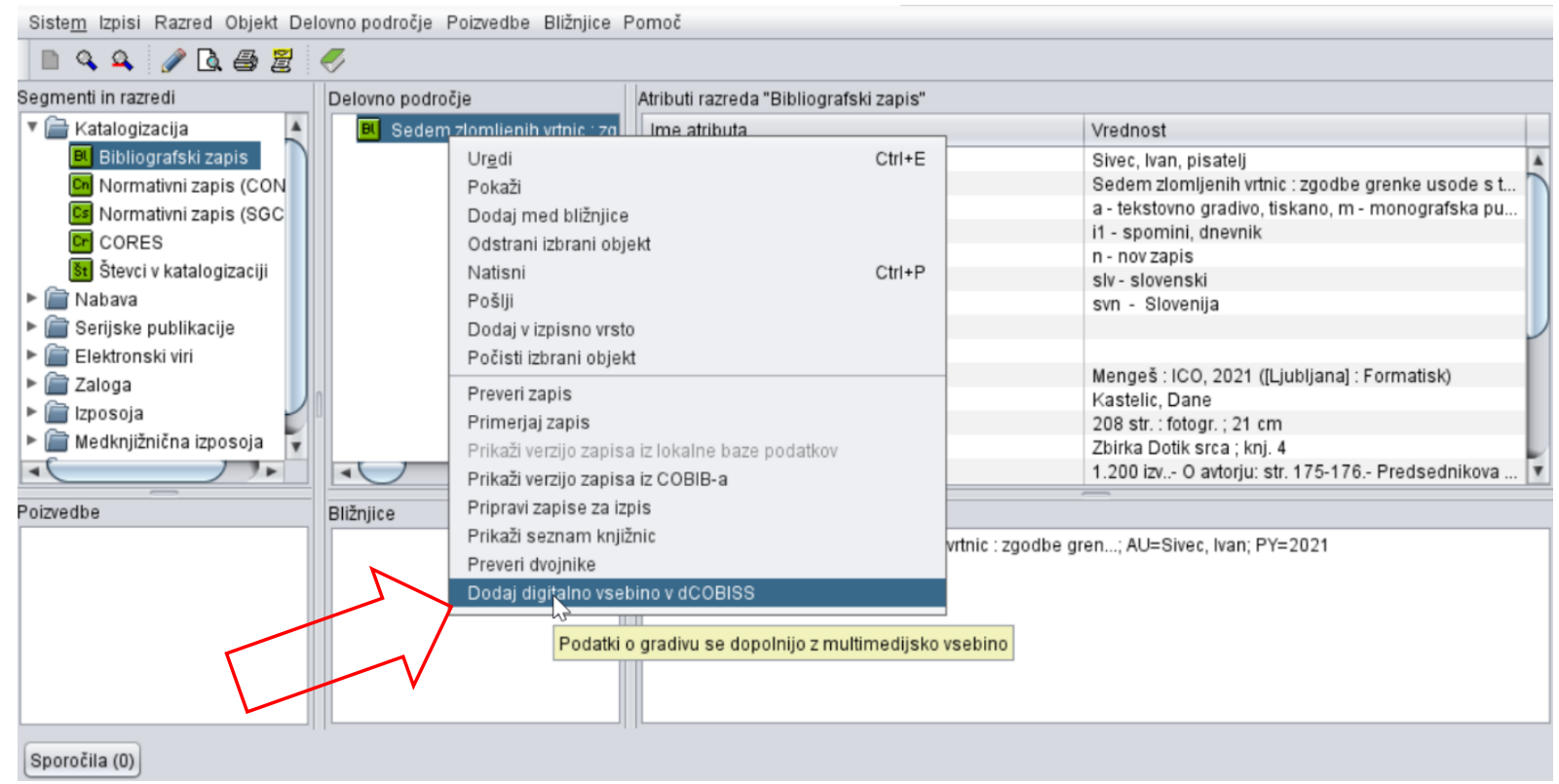

Slika 4: Prehod v dCOBISS iz aplikacije COBISS3 brez ponovne prijave

Aplikacija dCOBISS se lahko uporablja za splošne potrebe $v$ vseh knjižnicah in za specifične potrebe $v$ akademskem okolju. 


\subsection{Uporaba dCOBISS za splošne potrebe}

Aplikacija dCOBISS je namenjena in dostopna vsem knjižnicam v sistemu COBISS. Tako lahko knjižničarji, ne glede na tip knjižnice, k obstoječim bibliografskim zapisom v COBISS-u dodajajo datoteke $z$ digitalnimi vsebinami, ki se vsebinsko nanašajo na bibliografski zapis, in tako obogatijo zapise, ki so najdljivi v COBISS+.

V prvem letu uporabe se je pokazalo, da knjižničarji aplikacijo dCOBISS uporabljajo predvsem za vnos naslovnic bibliografskih virov, za katere so kreirani bibliografski zapisi; te naslovnice so potem vidne uporabnikom $v$ COBISS+. Vendar pa lahko $v$ dCOBISS poleg naslovnic knjig ali prikaznih slik člankov dodajamo tudi multimedijske vsebine, slike, razglednice, fotografije, prosojnice, besedilne datoteke in tudi celotna besedila itn. Aplikacija podpira vrsto različnih formatov oz. datotek, kot so pdf, doc, ppt idr. (Celoten seznam je dostopen na https://d.cobiss.net/repository/si/help/supported-media-types.).

V COBISS3 je bilo mogoče že pred izdajo aplikacije dCOBISS dodajati multimedijske vsebine. To rešitev, staro več kot 20 let, je zdaj nadomestila aplikacija dCOBISS in skoraj 30.000 datotek predhodnega repozitorija je bilo prenesenih v novo aplikacijo.

\subsubsection{Naslovnice bibliografskih virov}

Aplikacija dCOBISS omogoča dodajanje slikovnih datotek - naslovnic bibliografskih virov, ki se lahko uporabijo ob bibliografskih zapisih (sliki 5 in 6).

\begin{tabular}{|c|c|c|c|c|c|c|c|}
\hline Ime datoteke in opis & Prikaži v COBISS+ & Besedilo & Glavna naslovr & ica & Pooblaščen dostop & Uredi & Izbriši \\
\hline $\begin{array}{l}\text { Kuhajmo-brez-glutena-:-kuharski-vodnik-od-naku } \\
\text { pov-do-recepto.jpg } \\
\text { velikost datoteke: } 42.85 \mathrm{~KB} \\
\text { Ustvarjalec: andrej@ossmar } \\
\text { Datum prenosa: } 7.7 .202109: 02 \\
\text { Datum spremembe: } 7.7 .202109 .02\end{array}$ & Prikazano & & 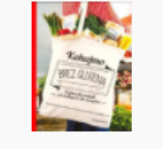 & $\nabla$ & & 8 & $x$ \\
\hline
\end{tabular}

Slika 5: Označitev prikazne slike v dCOBISS

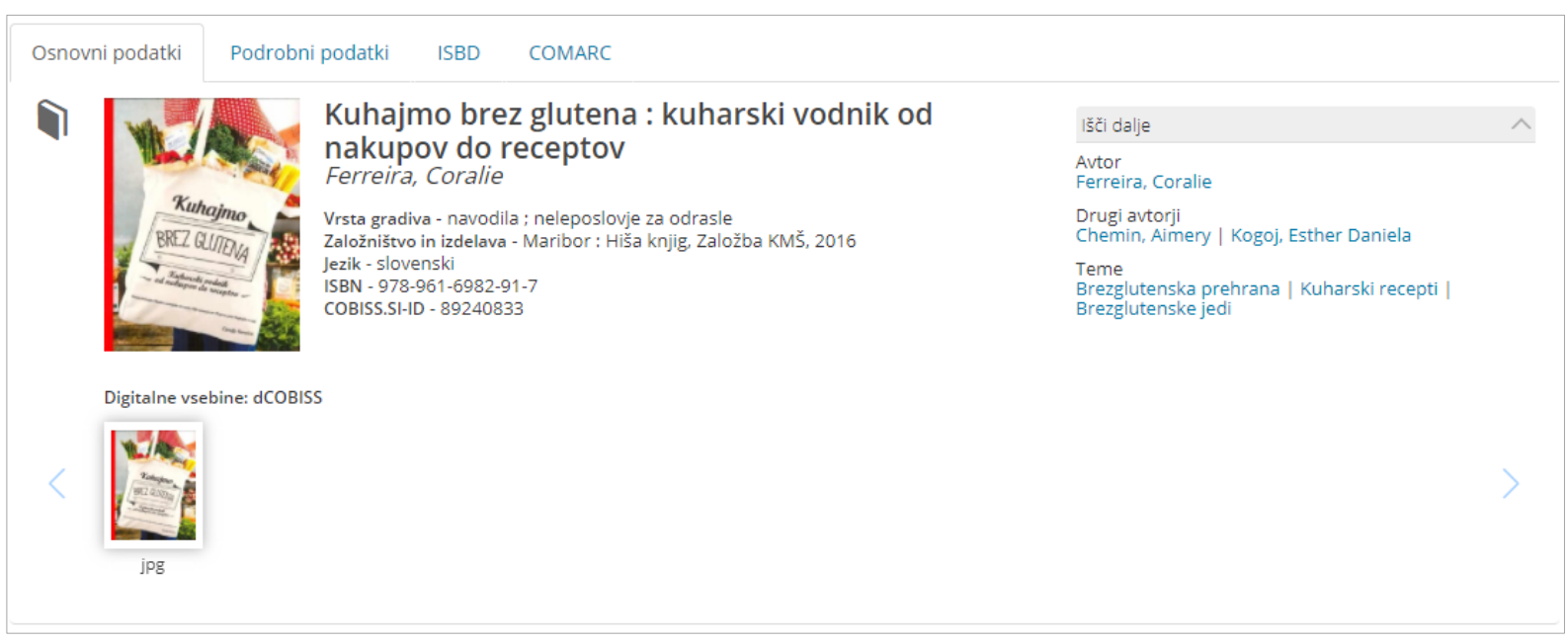

Slika 6: Prikaz naslovnice knjige Kuhajmo brez glutena v COBISS+

$\mathrm{V}$ primeru dodajanja datotek $\mathrm{v}$ formatu pdf ali ppt dCOBISS samodejno kreira slikovne datoteke, ki se lahko uporabijo kot prikazne slike. 
IZUM ima dogovor z Javno agencijo za knjigo Republike Slovenije (https://www.jakrs.si/) (2021) in ponudnikom servisa Dobreknjige.si (https://www.dobreknjige.si/) (2021) za samodejni prenos naslovnic knjig z omenjenih portalov $v$ dCOBISS. Dnevno se preverjajo in $v$ dCOBISS kopirajo nove naslovnice za namene prikaza ob bibliografskih zapisih v COBISS+. Tudi založnikom omogočamo dodajanje naslovnic knjig v dCOBISS, če to želijo.

\subsubsection{Razglednice, fotografije, multimedijske vsebine ipd.}

Že predhodni repozitorij je omogočal dodajanje datotek, v katerih so bile razglednice, fotografije in multimedijske vsebine. dCOBISS te možnosti upravljanja še dopolnjuje in razširja (sliki 7 in 8).

$\rightarrow$ C d.cobiss.net/repository/si/files/69521667/87083/NC00197_00210.jpg/terms
dCOBISS : Repozitorij $\vee$ Q Iskanje $\vee$ Upravljanje $\vee$

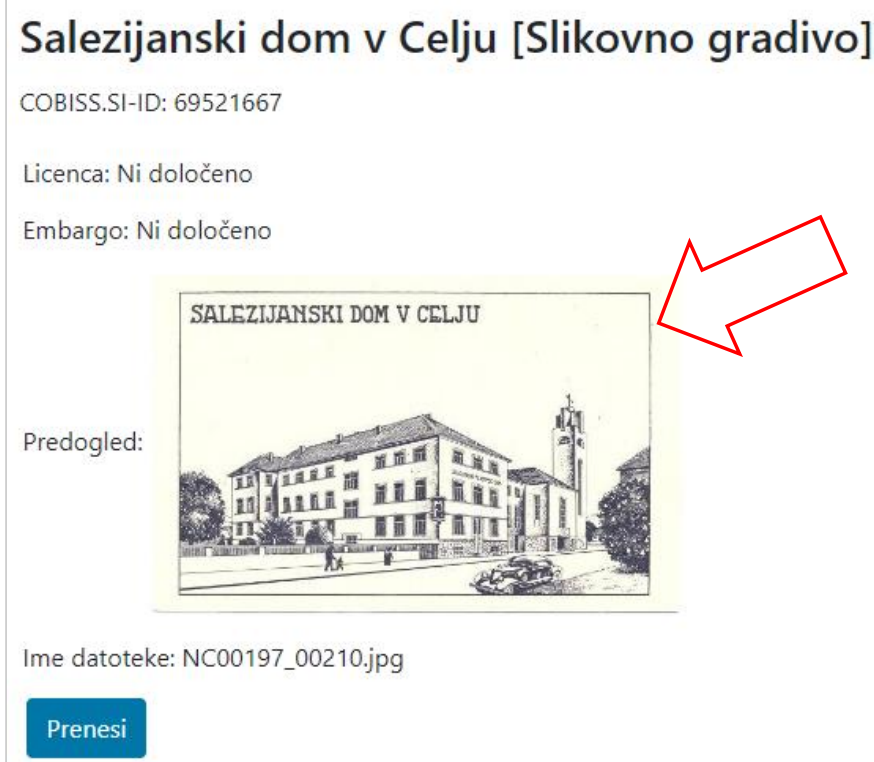

Slika 7: Prikaz slikovnega gradiva, ki si ga lahko uporabnik prenese in shrani brez omejitev

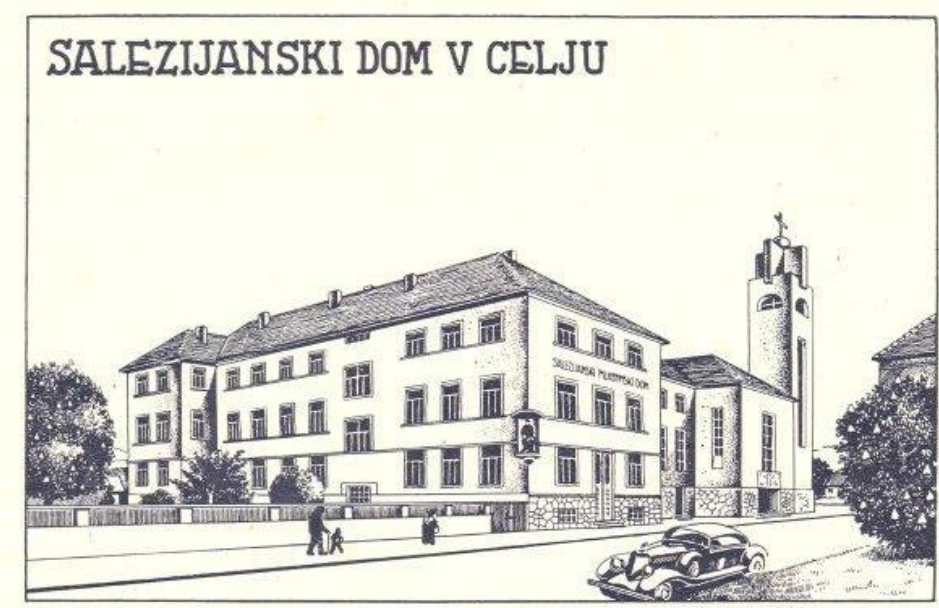

Slika 8: Slika, priložena k bibliografskemu zapisu, prikazuje Salezijanski dom v Celju med letoma 1937 in 1941 
Trenutno dCOBISS omogoča shranjevanje datotek do velikosti $1 \mathrm{~GB}$. Če bodo potrebe po velikosti datotek $v$ prihodnje večje, bomo to omejitev spremenili.

\subsubsection{Vsebine, najdljive in dostopne kot celotna besedila}

Shranjene besedilne datoteke $v$ dCOBISS, kot so članki, e-knjige, predstavitve in podobno, se samodejno pretvorijo $v$ datoteke $v$ formatu txt. Te datoteke dnevno indeksiramo za potrebe iskanja in uporabnikom $v$ COBISS+ omogočamo iskanje po celotnih besedilih, ki so bila shranjena $v$ dCOBISS (sliki 9 in 10).

a d.cobiss.net/repository/si/pub/editPublication/30900775

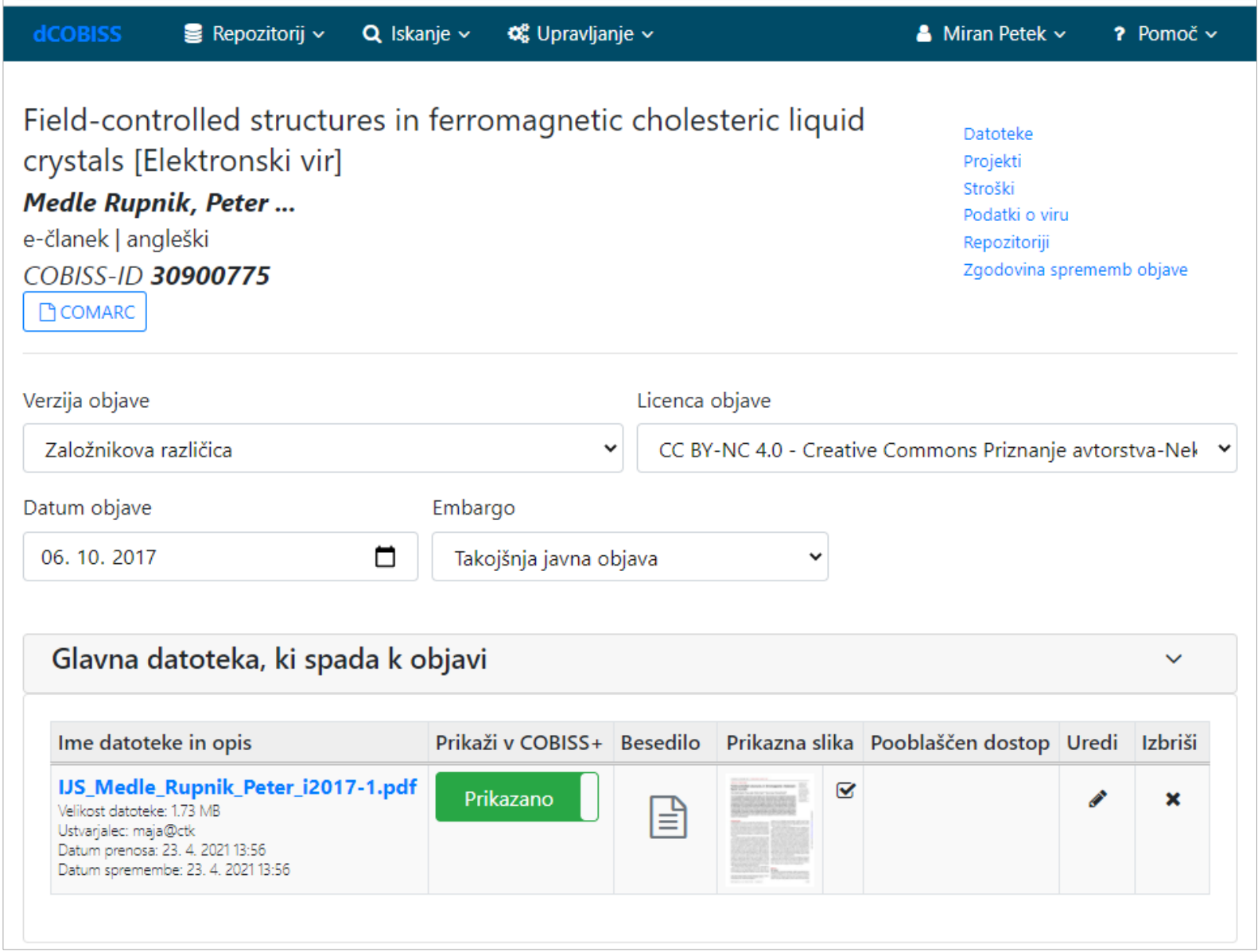

Slika 9: Članek, shranjen v dCOBISS 
$\rightarrow$ C plus.si.cobiss.net/opac $7 /$ bib/search?q=in+suspension + of + magnetic + nanoplatelets + in + clcs $\&$ db $=$ cobib \&mat $=$ allmaterials $\&$ max $=50$
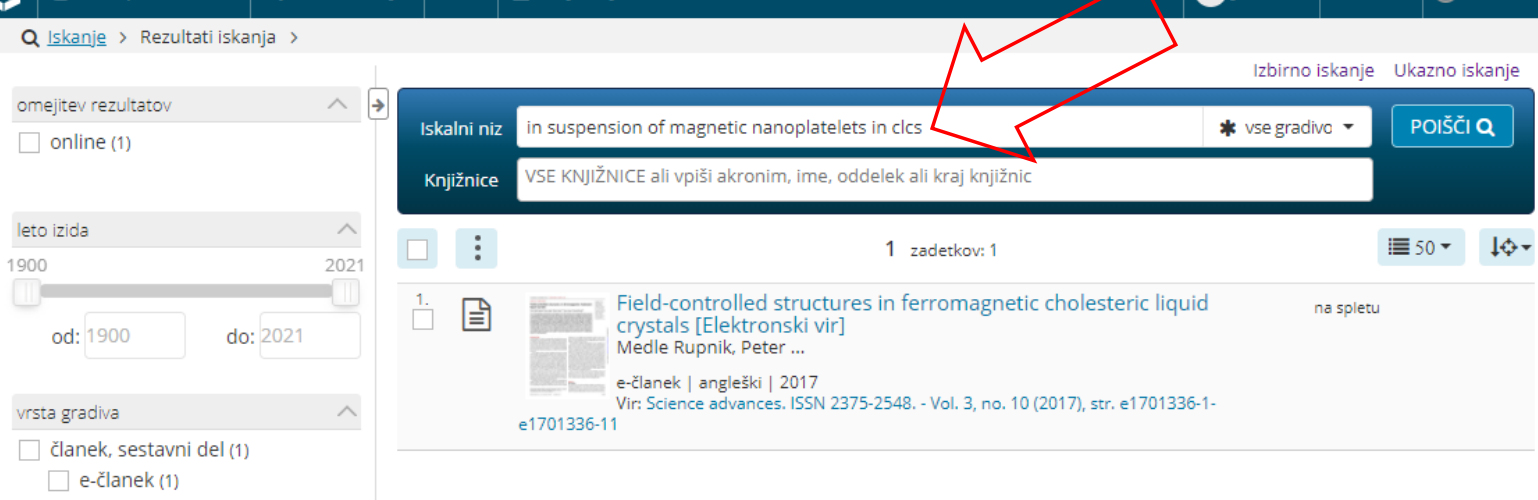

Slika 10: Članek, shranjen $v$ dCOBISS in najdljiv $v$ COBISS $+z$ iskanjem po besedah $v$ celotnem besedilu članka

V COBISS+ je omogočeno iskanje po celotnih besedilih tudi za vsebine, ki so bile pridobljene $\mathrm{s}$ sinhronizacijo $z$ institucionalnimi repozitoriji (slika 10). Trenutno je omogočena sinhronizacija vsebin z repozitorijem Digitalna knjižnica Univerze v Mariboru (DKUM) (Digitalna, 2021) in Repozitorijem Univerze v Ljubljani ( $\underline{\mathrm{RUL}}$ ). Ko se $\mathrm{v}$ institucionalni repozitorij vnese datoteka, ki izpolnjuje pogoje za sinhronizacijo $z$ dCOBISS, se vsebina $z$ besedilom prenese $v$ dCOBISS, po indeksiranju pa je v COBISS+ omogočeno iskanje po celotnem besedilu.

Sinhronizacija $z$ institucionalnimi repozitoriji zagotavlja, da se $v$ COBISS+ prikažejo povezave do spletnih naslovov zapisov $v$ institucionalnih repozitorijih. Trenutno se tako prikazujejo spletne povezave do zapisov repozitorijev Univerze v Maribor (DKUM) in Univerze v Ljubljani $(\underline{R U L})$.

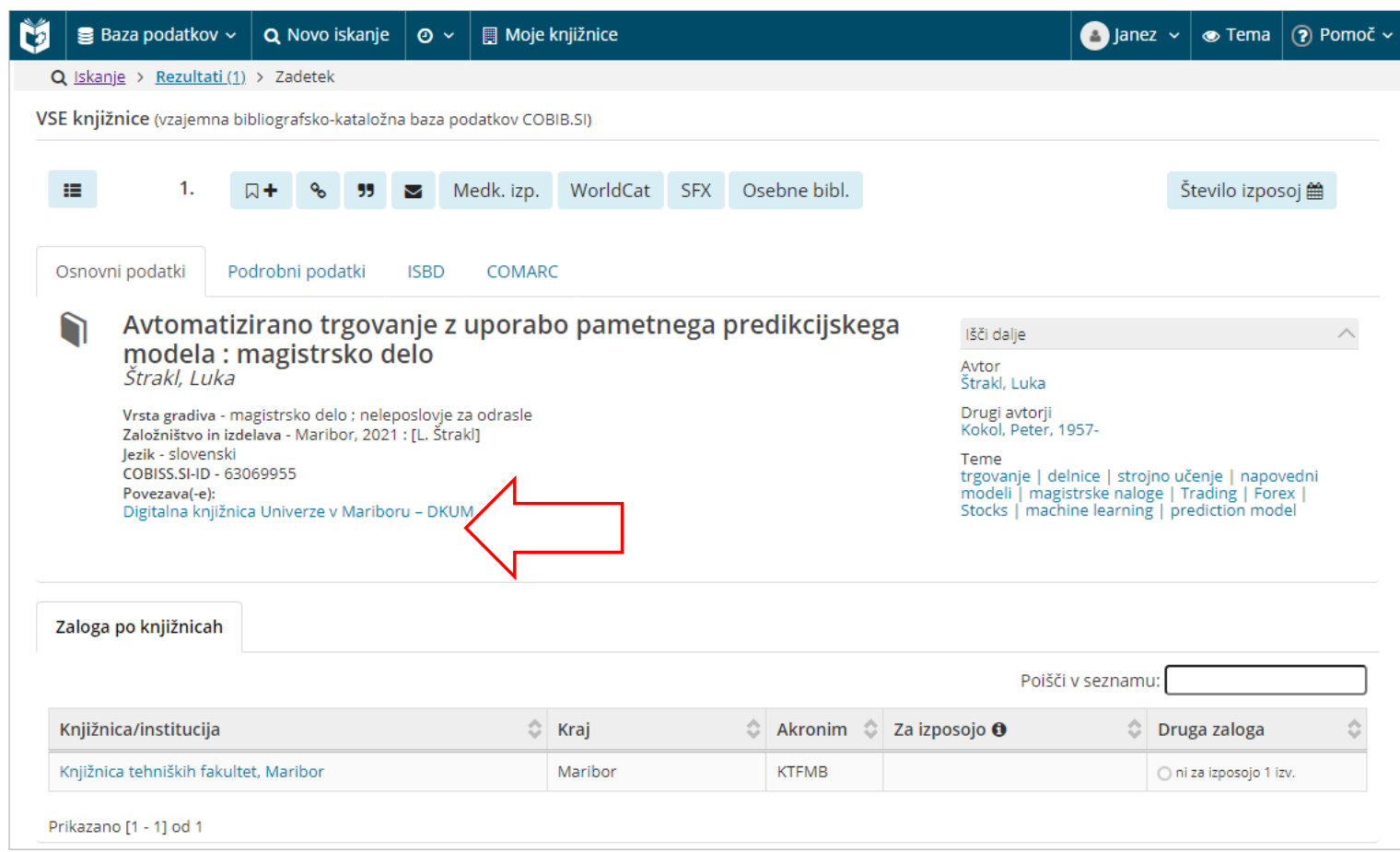

Slika 11: Povezava do magistrskega dela, ki je shranjeno v univerzitetnem repozitoriju DKUM 


\subsubsection{Omejevanje dostopa oz. avtoriziran dostop do vsebin v dCOBISS}

Knjižnice lahko v dCOBISS shranijo tudi takšne digitalne vsebine, do katerih smejo dostopati le določene skupine uporabnikov. Te skupine so lahko npr. vsi člani določene knjižnice ali le študentje in zaposleni na univerzi ali fakulteti itd. (sliki 11 in 13).

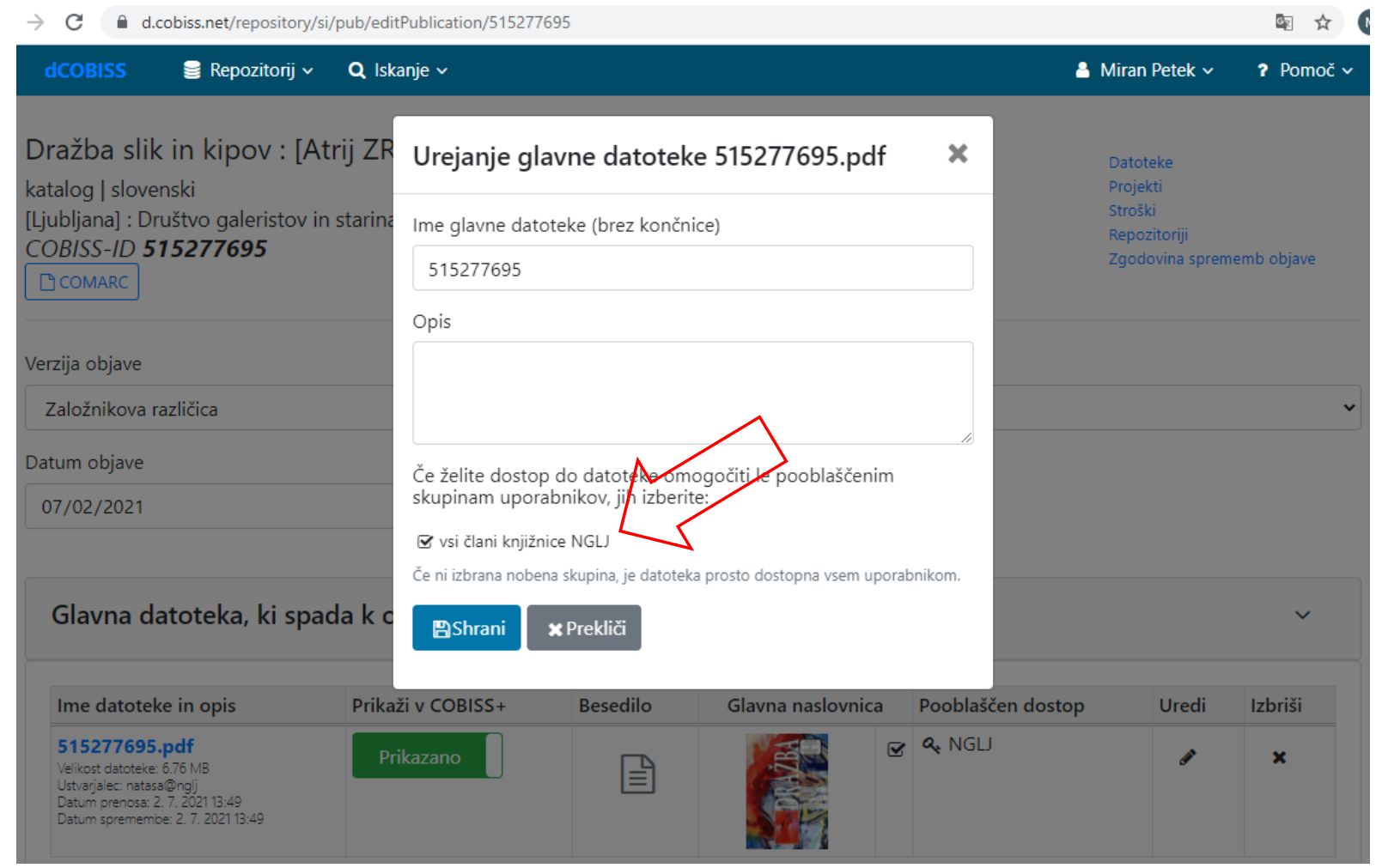

Slika 11: Datoteka v formatu pdf bo dostopna le članom knjižnice Narodne galerije v Ljubljani

Če si želi uporabnik ogledati vsebino takšne datoteke, se mora prijaviti v COBISS+.

\subsubsection{Dodajanje datotek v dCOBISS in avtorske pravice}

Pri dodajanju datotek $v$ dCOBISS mora biti knjižničar pozoren na spoštovanje avtorskih pravic. Potrditi mora, da je seznanjen s pravili o avtorskih pravicah, ki so opisane na spletni strani https://www.cobiss.si/avtorske-pravice-dcobiss.htm (sliki 12 in 13) (Avtorske, 2021). 


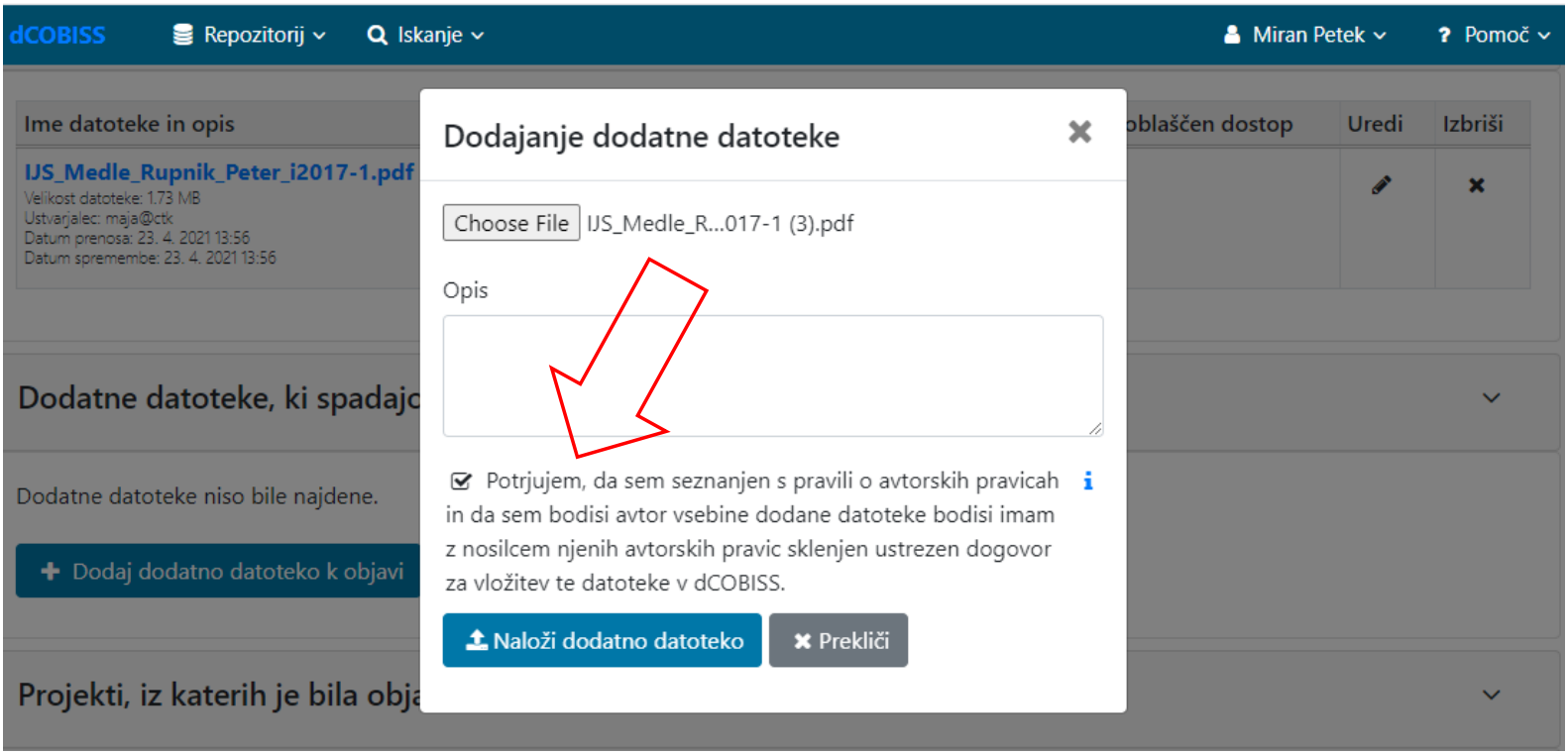

Slika 12: Obvezna potrditev, da smo seznanjeni s pravili o avtorskih pravicah ob dodajanju datotek $v$ dCOBISS

\section{dCOBISS}

Dražba slik in kipov : [Atrij ZRC SAZU, 15. december 2013]

COBISS.SI-ID: 515277695

Licenca: InC - In Copyright

Embargo: Ni določeno

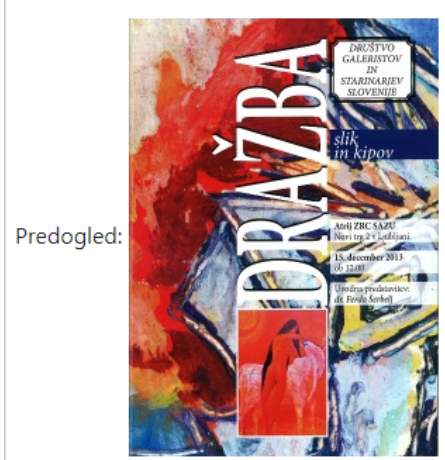

Ime datoteke: 515277695.pdf

Datoteka je na voljo samo pooblaščenim up Za dostop do datoteke se je treba prijaviti.

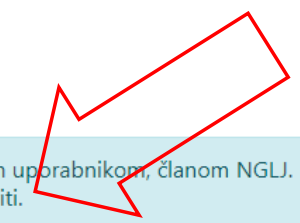

$\rightarrow$ Prijava z vpisnimi podatki Moje knjižnice (COBISS AAI)

Slika 13: Za ogled določenih vsebin je potrebna prijava v COBISS+

Knjižnica, ki želi omogočiti dostop do vsebin le določenim uporabniškim skupinam, se glede pogojev, ki jih mora uporabnik izpolnjevati, dogovori z IZUM-om. Avtorizacija se izvede na osnovi kontrole vpisnih podatkov članov v segmentu COBISS3/Izposoja (slika 13). 


\subsection{Uporaba dCOBISS za akademsko-raziskovalne namene}

Poleg splošne uporabe dCOBISS za namene hranjenja najrazličnejših datotek se repozitorij uporablja tudi za spremljanje objav slovenskih raziskovalcev v odprtem dostopu (slika 14).
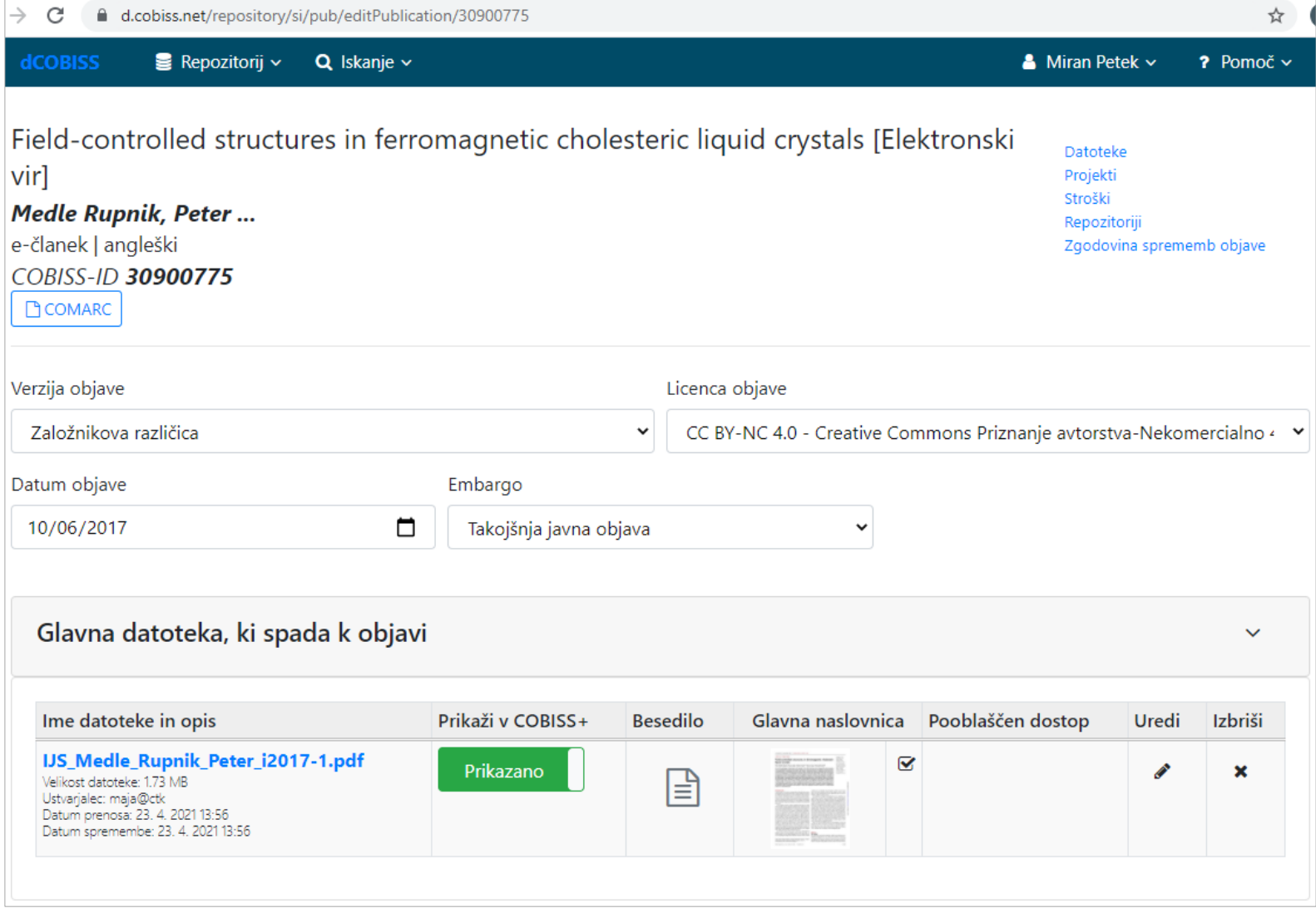

Slika 14: Članek v odprtem dostopu, shranjen v dCOBISS

Knjižničar lahko shrani podatke o objavi članka oz. dela raziskovalca, kot so verzija objave, licenca objave, datum objave in embargo. Kot glavno datoteko lahko doda članek, shranjen v formatu pdf. Dodatno lahko priloži prikazno sliko članka, ki bo vidna ob zapisu COBISS+. Lahko doda tudi druge dodatne datoteke, ki se nanašajo na vsebino članka, morda grafikone in slike iz priloženega članka itd.

Za objave v odprtem dostopu je pomembna izbira prave licence (licence Creative Commons, opisane na spletni strani: https://creativecommons.org/licenses/?lang=sl).

Za vsebine, ki bodo dostopne po poteku določenega časa (embarga), se lahko v dCOBISS določi datum, do katerega je uporabnikom v COBISS+ vsebina nedostopna. Enako velja za trajno nedostopne vsebine, ki se $v$ repozitorij shranjujejo zaradi trajnega arhiviranja.

Poleg omenjenih podatkov o objavi se $v$ dCOBISS shranjujejo tudi podatki o projektih, financerjih, plačnikih in stroških objave v odprtem dostopu (slika 15). 


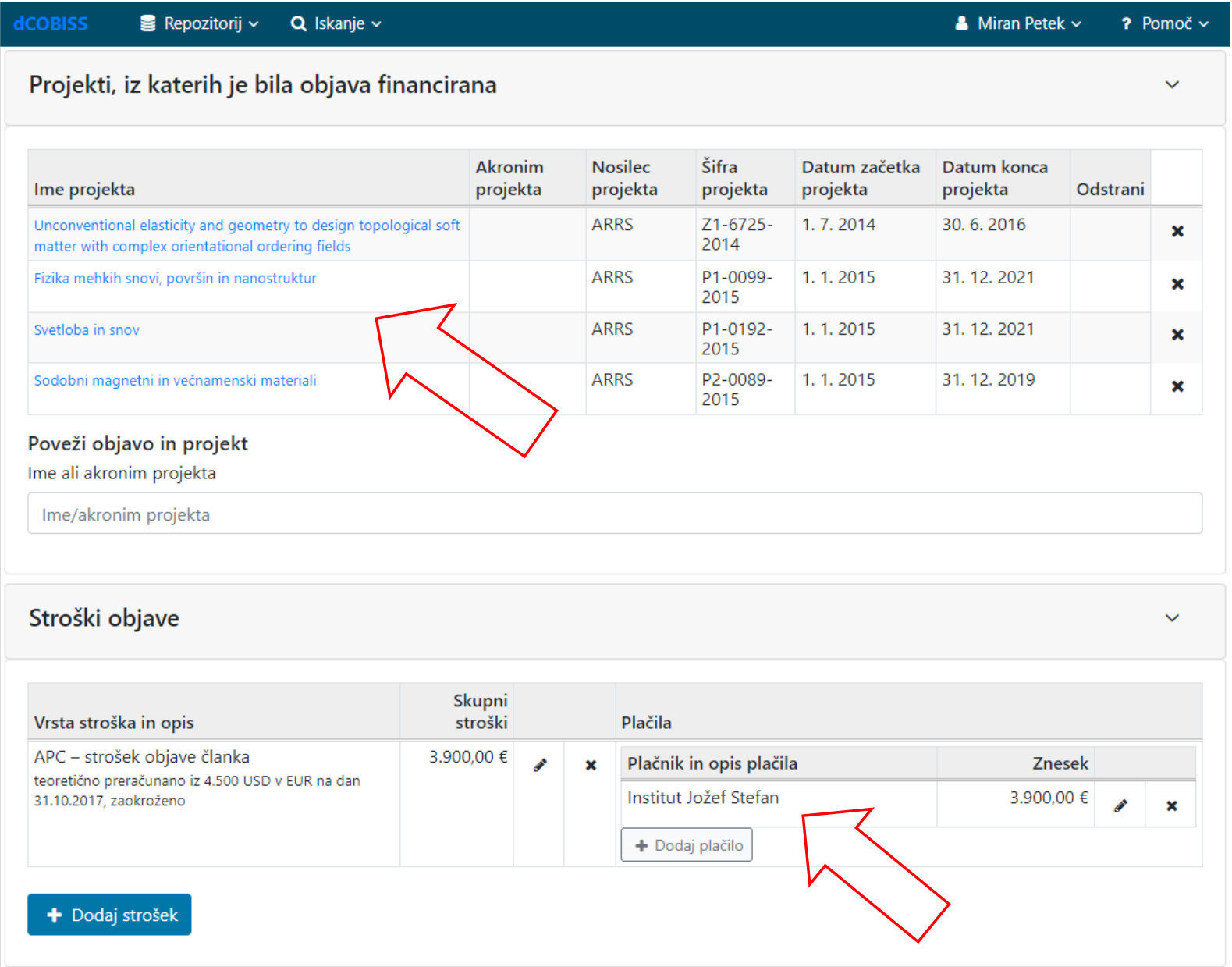

Slika 15: Z objavo članka v odprtem dostopu so povezani projekti, ki jih financira ARRS, in stroški objave, ki jih je plačal Institut Jožef Stefan

V dCOBISS so vključeni vsi projekti, ki jih financira ARRS, in vsi mednarodni projekti, ki jih pridobivamo s spletnega portala OpenAIRE (2021).

Za objave v odprtem dostopu lahko založniki avtorjem obračunajo nadomestilo. Pri člankih gre za APC (Article Processing Charge), pri knjigah za BPC (Book Processing Charge), pri objavah poglavij za BCPC (Book Chapter Processing Charges) in pri konferenčnih objavah za CPC (Chapter Processing Charge). V dCOBISS je mogoče vpisati tudi podatek o plačniku in vrednost stroška v evrih.

Tovrstne objave se shranjujejo tudi $v$ institucionalne digitalne repozitorije univerz in drugih raziskovalnih institucij. Med dCOBISS-om in institucionalnimi repozitoriji se izvaja sinhronizacija podatkov (slika 16). 


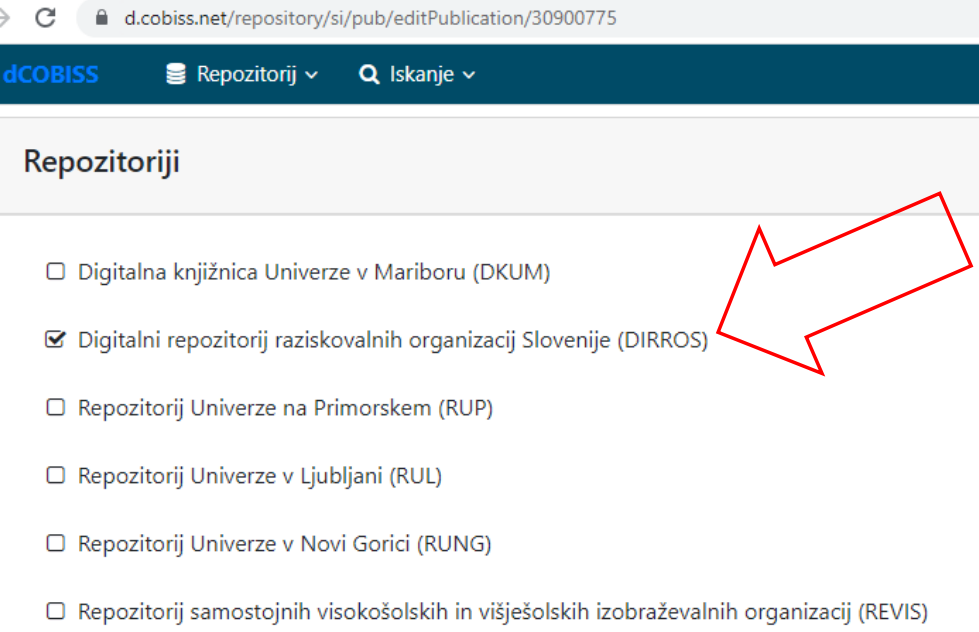

Slika 16: Ob objavi članka iz odprtega dostopa je označen repozitorij DiRROS za potrebe sinhronizacije podatkov med obema repozitorijema

V Sloveniji obstaja nacionalna infrastruktura odprtega dostopa do zaključnih študijskih del in objav raziskovalcev, ki je sestavljena iz štirih institucionalnih repozitorijev slovenskih univerz (DKUM, RUL, RUP in $\underline{R U N G}$ ), repozitorija raziskovalnih organizacij Slovenije (DiRROS), repozitorija samostojnih visokošolskih in višješolskih izobraževalnih organizacij ( $\underline{\operatorname{ReVIS}}$ ) in Nacionalnega portala odprte znanosti (https://openscience.si/) (2021). Zaradi možnosti analize odprtega dostopa, ki naj bi jo v prihodnje zagotavljal dCOBISS, se tovrstni podatki sinhronizirajo tudi z objavami $v$ dCOBISS.

Digitalne vsebine so najdljive tudi, če iščemo po besedah, ki se pojavljajo $v$ celotnih besedilih (ne le $v$ bibliografskem delu zapisa) $v$ COBISS+. Najdljive so tudi na vseh portalih COBISS+ ( $\underline{A D Z}$, DiKUL, mEga iskalnik NUK, UM:NIK, Digital:UP; gl. Portal ..., 2021), kjer obstajajo spletne povezave do teh celotnih besedil. To je pomembna funkcionalnost orodja za odkrivanje informacij (Akademska digitalna zbirka Slovenije - ADZ) (2021) (slika 17). Podatki o objavi v dCOBISS so vidni ob bibliografskih zapisih v COBISS+. 
a plus-adz.si.cobiss.net/opac7/bib/30900775\#oad

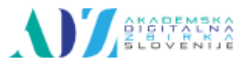

Q Iskanje > Rezultati (1) > Zadetek

VSE knjižnice (vzajemna bibliografsko-kataložna baza podatkov COBIB.SI)

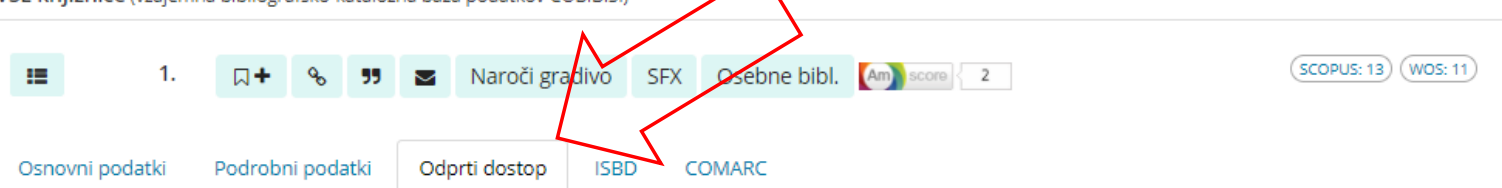

Osnovni podatki Podrobni podatki Odprti dostop ISBD COMARC

\begin{tabular}{l|l}
\hline Avtor & Medle Rupnik, Peter ... \\
\hline Naslov & Field-controlled structures in ferromagnetic cholesteric liquid crystals [Elektronski vir] \\
\hline COBISS.SI-ID & 30900775 \\
\hline Verzija publikacije & Založnikova različica \\
\hline Licenca publikacije & Creative Commons Priznanje avtorstva-Nekomercialno 4.0 Mednarodna \\
\hline Datum objave & $2017-10-06$ \\
\hline Embargo & Takojšnja javna objava \\
\hline
\end{tabular}

Projekti, iz katerih je bila financirana objava

\begin{tabular}{|l|l|l|l|}
\hline Naziv & Akronim & Številka projekta & Financer \\
\hline Svetloba in snov & & P1-0192 & $\begin{array}{l}\text { Javna agencija za raziskovalno } \\
\text { dejavnost }\end{array}$ \\
\hline Sodobni magnetni in večnamenski materiali & & P2-0089 & $\begin{array}{l}\text { Javna agencija za raziskovalno } \\
\text { dejavnost }\end{array}$ \\
\hline Fizika mehkih snovi, površin in nanostruktur & P1-0099 & Javna agencija za raziskovalno \\
dejavnost
\end{tabular}

\section{Datoteke, ki spadajo k objavi}

Povezava

口 https://d.cobiss.net/repository/si/files/30900775/80010/IS_Medle_Rupnik_Peter_i2017-1.pdf

\section{Stroški objave}

\begin{tabular}{|l|l|l}
\hline Vrsta stroška & Skupni stroški & Plačila \\
\hline APC - strošek objave članka & 3900.00 & 3900.00 : Institut Jožef Stefan
\end{tabular}

Slika 17: Na portalu ADZ so na zavihku Odprti dostop prikazani podatki o objavi članka, shranjenega v dCOBISS

\section{Nadaljnji razvoj}

Aplikacija dCOBISS se kontinuirano razvija. Do objave tega prispevka je dočakala že nekaj nadgradenj. dCOBISS je že kompatibilen z mednarodno platformo OpenAIRE, v postopku pa je še dodajanje povezave, ki bo omogočala pretakanje podatkov iz dCOBISS v OpenAIRE (2021).

$V$ nadaljevanju želimo knjižnicam omogočiti vpogled $v$ uporabo shranjenih vsebin $v$ dCOBISS, torej statistične preglede uporabe predvsem za akademsko-raziskovalne institucije, ki želijo pregled nad porabljenimi sredstvi za objavljanje $v$ odprtem dostopu. Pripraviti želimo analitično orodje znotraj dCOBISS, ki bo namenjeno pripravi poročil v zvezi z objavljanjem $v$ odprtem dostopu za Javno agencijo za raziskovalno dejavnost in druge institucije. Prilagajali se bomo novim zahtevam in potrebam knjižnic, ki se zelo hitro spreminjajo, in sledili 
mednarodnim trendom odprte znanosti. Kot agregator vsebin institucionalnih repozitorijev $\mathrm{v}$ Sloveniji bi lahko dCOBISS postal nacionalni referenčni digitalni repozitorij.

Aplikacija dCOBISS se bo v prihodnje še tesneje povezovala z drugimi IZUM-ovimi aplikacijami. To velja predvsem za naslednji generaciji aplikacij COBISS in SICRIS, ki se že intenzivno pripravljata. Tako knjižničarjem kot končnim uporabnikom želimo ponuditi sodobna orodja, ki jih uporabljajo za iskanje informacij v službene namene in v prostem času, seveda pa tudi za študijsko, izobraževalno in raziskovalno delo.

Za uspešen razvoj je zelo pomembno tesno sodelovanje s partnerskimi knjižnicami in končnimi uporabniki naših storitev. Drugačna mnenja, sveže pobude in nove ideje so ključni pri razvoju aplikacije dCOBISS. Posredovati jih je možno prek uporabniškega portala, ki je namenjen zbiranju tovrstnih predlogov (https://jira.izum.si/servicedesk/customer/portal/8).

\section{Reference}

Akademska digitalna zbirka Slovenije (ADZ), 2021. Dostopno na: https://adz.cobiss.si/ [26. 8. 2021].

Avtorske pravice pri vlaganju v dCOBISS, 2021. Dostopno na: https://www.cobiss.si/avtorskepravice-dcobiss.htm [26. 8. 2021].

Digitalna knjižnica Univerze v Mariboru (DKUM), 2021. Dostopno na: https://dk.um.si/ [26. 8. 2021].

Digitalni repozitorij COBISS.SI, 2020. Dostopno na: https://d.cobiss.net/repository/si [26. 8. 2021].

Digitalni repozitorij dCOBISS.Net, 2020. Dostopno na: https://d.cobiss.net/repository [26. 8. 2021].

Digitalni repozitorij raziskovalnih organizacij Slovenije (DIRROS), 2021. Dostopno na: http://dirros.openscience.si/ [26. 8. 2021].

Javna agencija za knjigo RS, 2021. Dostopno na: https://www.jakrs.si/ [26. 8. 2021].

Licence Creative Commons, 2021. Dostopno na:

https://creativecommons.org/licenses/?lang=sl [26. 8. 2021].

Nacionalni portal odprte znanosti, 2021. Dostopno na: https://openscience.si/ [26. 8. 2021].

Petek, M., 2020. Digitalni repozitorij COBISS - dCOBISS. Blog COBISS, 16. 11. 2020. Dostopno na: https://blog.cobiss.si/2020/11/16/dcobiss/ [26. 8. 2021].

Podprte vrste datotek v dCOBISS, 2020. Dostopno na:

https://d.cobiss.net/repository/si/help/supported-media-types [26. 8. 2021].

Portal ADZ, 2021. Dostopno na: https://plus-adz.si.cobiss.net/opac7/ [26. 8. 2021].

Portal COBISS+, 2021. Dostopno na: https://plus-ul.si.cobiss.net/opac7/ [26. 8. 2021].

Portal Digital:UP, 2021. Dostopno na: https://plus-up.si.cobiss.net/opac7/ [26. 8. 2021]. 
Portal mEga iskalnik NUK, 2021. Dostopno na: https://plus-nuk.si.cobiss.net/opac7/ [26. 8. 2021].

Portal OpenAIRE, 2021. Dostopno na: https://www.openaire.eu/ [26. 8. 2021].

Portal UM:NIK, 2021. Dostopno na: https://plus-um.si.cobiss.net/opac7/ [26. 8. 2021].

Repozitorij Univerze na Primorskem, 2021. Dostopno na: https://repozitorij.upr.si/ [26. 8. 2021].

Repozitorij Univerze v Ljubljani, 2021. Dostopno na: https://repozitorij.uni-lj.si/ [26. 8. 2021].

Repozitorij samostojnih visokošolskih in višješolskih izobraževalnih organizacij, 2021.

Dostopno na: http://revis.openscience.si/ [26. 8. 2021].

Spletni portal Dobreknjige.si, 2021. Dostopno na: https://www.dobreknjige.si/ [26. 8. 2021]. 